\title{
An analysis of secured and unsecured borrowing performance of the power corporations of Haryana: 2001-2010
}

\author{
Ms. Vanita \\ Assistant professor, om institute of management and technology, juglan (Hisar)
}

\begin{abstract}
Secured and unsecured borrowings shows the current status of the power sector whether the corporation is generating revenue or not the status shows it needs a lot of improvement on various points. For secured borrowings HPGCL \& HVPNL needs lots of improvement and for unsecured borrowings
\end{abstract} DHBVNL needs to improve alot

Key words: borrowings, improvement, revenue

Secured borrowings are those in which the creditor has some rights over the assets of the debtor in the event of the latter being unable to repay the debts. Secured Borrowing Performance (SBP) of the four corporations is counted by dividing secured loans with total assets of each corporation one by one.

The assessment of secured borrowing performance of the four corporations will advise whether there is significant change has been recorded in secured borrowing performance of the four corporations or not in relation to. For this the average secured borrowing performance of each corporation is compared with the average secured performance of power sector Haryana.

Unsecured Borrowing Performance (USBP) of the four corporations is shaped by dividing unsecured loans over total assets one by one . Measuring this performance is quite important because of this a trend is came to know about loans of the four corporations individually. Unsecured Borrowing Performance (USBP) of the foru corporations is formed by dividing unsecured loans over total assets individually. Calculating this performance is quite essential because of this a trend is came to know about loans of the four corporations. The assessment of secured borrowing performance of the four corporations will advise whether there is significant change has been recorded in secured borrowing performance of the four corporations or not in relation to. For this the average secured borrowing performance of each corporation is compared with the average secured performance of power sector Haryana. If we compare secured and unsecured borrowing performances then secured borrowings are preferred because these are given on security and usually given for a long time.

\section{Interest on Loans}

The HVPNL estimate of interest of Rs. 1,737.35 million on loans included interest on new loans, other financial charges, interest on provident fund liability and excludes pension fund liability. The staff considered that all the loans contemplated for externally assisted projects would not materialise during the current year and therefore, proposed to disallow the interest on the same. The staff also noted that HVPNL did not submitted instrument-wise details of loans and details of the bonds issued to NTPC and NHPC.

HVPNL, in their response submitted that the interest on loans is calculated in respect of loans raised in FY 1999-2000 and it has not included additional borrowing for 2000-01. The additional loans already raised include NTPC bonds of Rs. 250 crore, NHPC bonds of Rs. 300 crore, bonds of Rs. 131 crore raised through market subscription, and loans of Rs. 60 crore obtained from Commercial Banks, with a total annual interest burden of Rs. 91.88 crore Besides these, the licensee would receive Rs. 144.4 crore additional loan in 2000-01 from a number of other sources like PFC, IBRD, etc. with an annual interest of Rs. 9.39 crore. Thus the total interest based on the staff calculation after adding the additional loans and bonds comes to Rs. 213.02 crore $^{1}$.

HVPNL filed detailed comments on the objections raised by various organisations and individuals. As regards the complaints by majority of the interveners about the un-reliable and poor power supply conditions, the licencee in their reply stated that poor quality of power is caused by several factors; such as, operating parameters of the grid, constrains on capacity of transformers, need for new grid substations and transmission lines and augmentation of capacity of existing substations. The licensee also explained the measures, which are

\footnotetext{
${ }^{1}$ herc.gov.in/orders/html/trftbs_00_01/chap2_1.html
} 
An analysis of secured and unsecured borrowing performance of the power corporations...

being taken for making improvements by augmentation of capacity of existing substations under the World Bank loan.

In regard to the public comments regarding high transmission and technical losses, the licensee submitted that transmission losses are $8 \%$ and accurate transmission losses would be quantified once the interface metering has been completed. The utility also did not agree with the public comments that nontechnical losses were as high as approximately 16 to $17 \%$.

HVPNL filed additional information and supplementary explanations on the issues that arose during the public hearings on 14th November 2000. The replies of the utility to the objections and comments of the public have been dealt with by the Commission in its order in subsequent chapters.

\section{Research Methodology}

Hypotheses of the Empirical Research

$>\quad \mathbf{H}_{01}$ The secured and unsecured loan performance of the power sector is not statistically increased.

FINANCIAL RATIOS:

Amount of secured loan

Secured Borrowing Performance $(\mathrm{SBP})=$

Amount of Fixed Assets

To analysis the secured borrowing performance of the four corporations of power sector

Amount of unsecured loan

Unsecured borrowing performance $(\mathrm{USBP})=$

Amount of Fixed Assets

To analysis the unsecured borrowing performance of the four corporations of power sector

Number of units and time period for study:

\begin{tabular}{|c|l|l|}
\hline $\begin{array}{l}\text { Sr. } \\
\text { No. }\end{array}$ & \multicolumn{1}{|c|}{ Name of Haryana Power Unit } & Period for study \\
\hline 1 & Dakshin Haryana Bijli Vitram Nigam Limited & 2001 to 2010 \\
\hline 2 & Uttar Haryana Bijli Vitran Nigam Limited & 2001 to 2010 \\
\hline 3 & Haryana Power Generation Corporation Limited & 2001 to 2010 \\
\hline 4 & Haryana Vidyut Prasaran Nigam Limited & 2001 to 2010 \\
\hline
\end{tabular}

The present study has used one sample $t$ test as the statistical tools for getting the empirical results.

The ratios under consideration are compared to power sector average ratio to find the significant value by employed t-test at $5 \%$ level of significance. The power sector average is calculated as follow:

Sector Average $=$

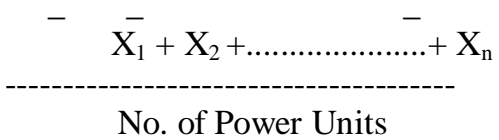

\section{Secured Borrowing Performance (SBP)}

Table: 1 Secured Borrowing Performance (SBP) of Dakshin Haryana Bijli Vitran Nigam Limited (DHBVNL) from 2001 to 2010

(In`crore)

\begin{tabular}{|l|l|l|l|}
\hline Year & Secured Loan & Total Assets & SBP \\
\hline 2001 & 16.26 & 1910.10 & 0.01 \\
\hline 2002 & 65.98 & 2032.17 & 0.03 \\
\hline
\end{tabular}


An analysis of secured and unsecured borrowing performance of the power corporations...

\begin{tabular}{|l|l|l|l|}
\hline 2003 & 106.59 & 2040.43 & 0.05 \\
\hline 2004 & 54.56 & 2553.42 & 0.02 \\
\hline 2005 & 92.16 & 2257.42 & 0.04 \\
\hline 2006 & 154.79 & 3116.15 & 0.05 \\
\hline 2007 & 256.26 & 2613.47 & 0.10 \\
\hline 2008 & 506.14 & 2879.46 & 0.18 \\
\hline 2009 & 931.64 & 5999.02 & 0.16 \\
\hline 2010 & 2631.26 & 8314.68 & 0.32 \\
\hline Average & $\mathbf{4 8 1 . 5 6}$ & $\mathbf{3 3 7 1 . 6 3}$ & $\mathbf{0 . 1 0}$ \\
\hline
\end{tabular}

SPSS calculations for One-Sample Test

\begin{tabular}{|l|l|l|l|l|l|l|}
\hline \multicolumn{2}{|l|}{ Test Value $=. \mathbf{1 5}$} \\
\hline & $\mathbf{t}$ & df & $\begin{array}{l}\text { Sig. } \\
\text { tailed })\end{array}$ & $(2-$ & $\begin{array}{l}\text { Mean } \\
\text { Difference }\end{array}$ & \multicolumn{2}{l|}{$\begin{array}{l}\text { 95\% Confidence Interval of } \\
\text { the Difference }\end{array}$} \\
\hline SBP & -1.744 & 9 & .115 & -.05400 & -.1240 & .0160 \\
\hline
\end{tabular}

Secured Borrowing Peformance

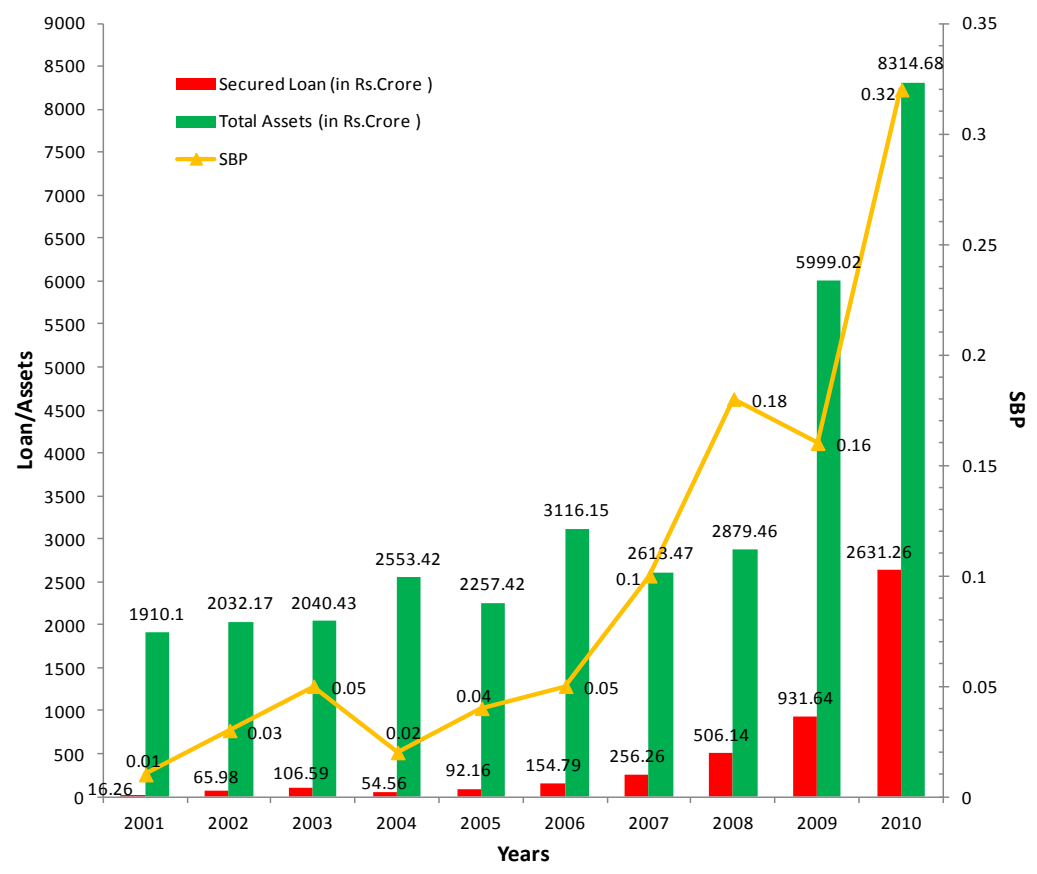

Graph :1

The secured borrowing performance (SBP) of the corporation has been shown by table and graph 1 . The irregular trend is observed in secured loan of the Nigam from 2001 to 2010. The highest secured loan is $` 2631.26$ crore whereas the lowest secured loan is ` 16.26 crore for 2001 . The average amount of secured loan is - 481.56 crore which is more as compared to the secured loan of 2001 to 2007. The fluctuating trend is observed in total assets of the Nigam from 2001 to 2010 . The highest amount of total assets is` 8314.68 crore whereas the lowest amount of total assets is ` 1910.10 crore for 2001 . The average amount of total assets is ` 3371.63 crore which is eight times more as compared to the average amount ( 481.56 crore) of secured loan. The SBP of the Nigam For 2001 is 0.01 which is thirty time less as compared to the SBP for $2010(0.32)$. SBP is rising continuously with slight fluctuation. The highest secured borrowing performance of the Nigam is 0.32 whereas 
An analysis of secured and unsecured borrowing performance of the power corporations... the lowest SBP is 0.01. (The industry SBP is 0.15) The SBP ratio is also tested through t-test (two-tailed) at $5 \%$ level of risk The testing value for SBP of the corporation is $\mathrm{t}=-1.744$ at $\mathrm{df}=9$ and not significant at 5 percent level of risk. Thus the secured borrowing performance of the Nigam is not significantly changed from 2001 to 2010.

Table : 2 Secured Borrowing Performance (SBP) of Uttar Haryana Bijli Vitran Nigam Limited (UHBVNL) from 2001 to 2010

\begin{tabular}{|l|l|l|l|}
\hline Year & Secured Loan & Total Assets & SBP \\
\hline 2001 & 14.64 & 2196.26 & 0.01 \\
\hline 2002 & 116.40 & 2092.82 & 0.06 \\
\hline 2003 & 236.84 & 2224.04 & 0.11 \\
\hline 2004 & 313.71 & 2436.32 & 0.13 \\
\hline 2005 & 320.75 & 2916.55 & 0.11 \\
\hline 2006 & 283.73 & 3096.49 & 0.09 \\
\hline 2007 & 522.44 & 4082.11 & 0.13 \\
\hline 2008 & 779.83 & 5344.09 & 0.15 \\
\hline 2009 & 2815.11 & 7871.73 & 0.36 \\
\hline 2010 & 4341.71 & 12370.40 & 0.35 \\
\hline Average & $\mathbf{9 7 4 . 5 2}$ & $\mathbf{4 4 6 3 . 0 8}$ & $\mathbf{0 . 1 5}$ \\
\hline
\end{tabular}

One-Sample Test

\begin{tabular}{|c|c|c|c|c|c|c|}
\hline & \multicolumn{6}{|c|}{ Test Value $=0.15$} \\
\hline & \multirow{2}{*}{$\mathbf{t}$} & \multirow{2}{*}{ df } & \multirow{2}{*}{$\begin{array}{l}\text { Sig. } \\
\text { tailed })\end{array}$} & \multirow{2}{*}{$\begin{array}{l}\text { Mean } \\
\text { Difference }\end{array}$} & \multicolumn{2}{|c|}{$\begin{array}{l}95 \% \text { Confidence Interval of the } \\
\text { Difference }\end{array}$} \\
\hline & & & & & Lower & Upper \\
\hline SBP & .000 & 9 & 1.000 & .00000 & -.0824 & .0824 \\
\hline
\end{tabular}


Graph : 2

\section{Secured Borrowing Peformance}

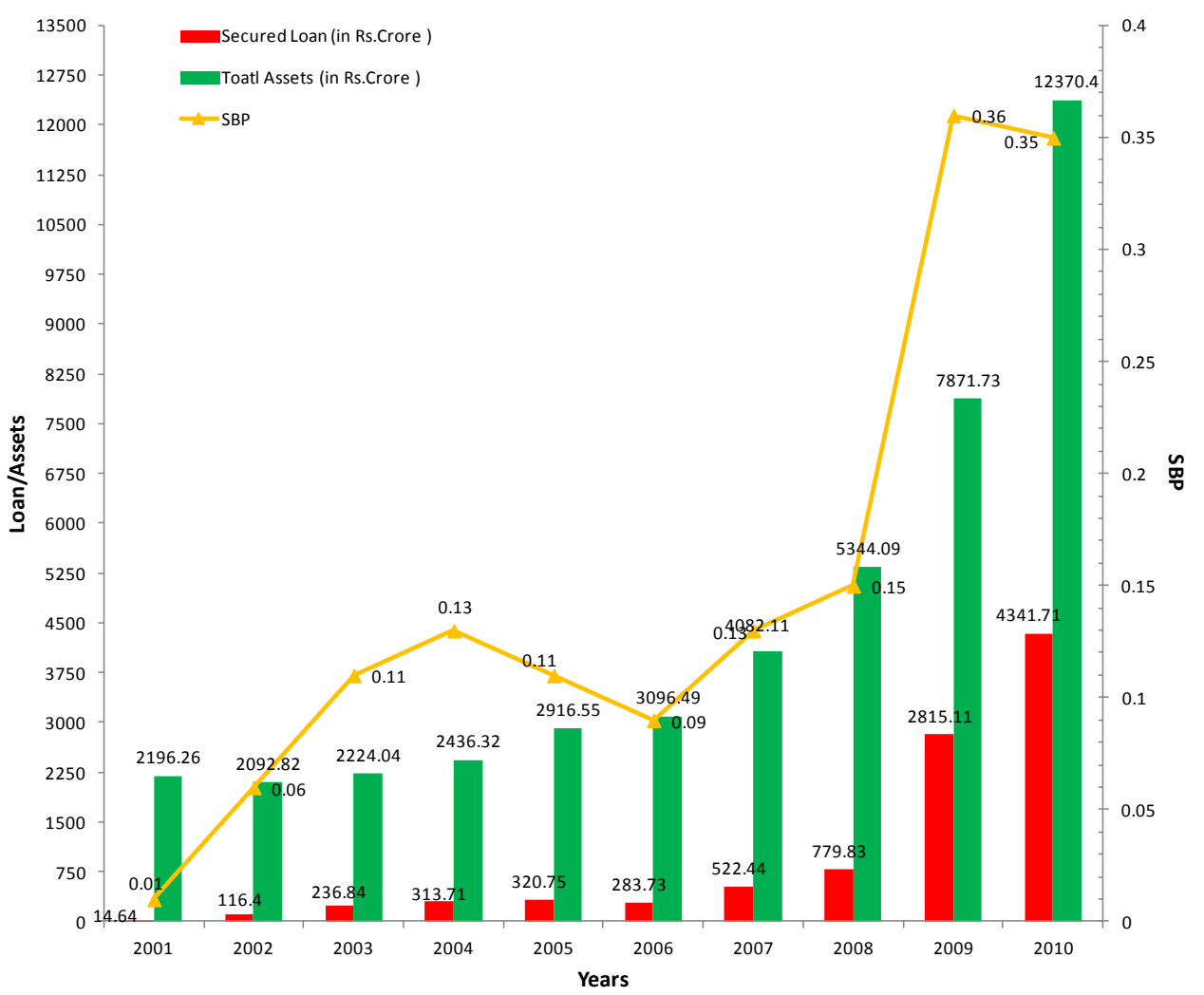

The secured borrowing performance of the Uttar Haryana Bijli Vitran Nigam Limited (UHBVNL) is shown by table and graph 2 from 2001 to 2010. The secured loan for 2001 is ` 14.64 crore whereas it raised upto to ` 116.40 crore for 2002. Thereafter, the amount of secured loan increased continuously from 2003 to 2010. The highest amount of loan is ` 4341.71 crore for 2010 whereas the lowest amount of secured loan is ` 14.64 crore for 2001. The average amount of loan is ` 974.52 crore for the period under consideration for the study. The fluctuating trend is observed in total assets of the Corporation from 2001 to 2010. The highest amount of total assets of the corporation is ' 12370.40 crore whereas the lowest amount of total assets of the firm is ' 2092.82 crore for 2002. The average amount of total assets of the Nigam is`4463.08 crore from 2001 to 2010. The average secured borrowing performance of the Vidut Nigam Ltd. is 0.15 that means, the $15 \%$ of the assets are secured against loan took by the corporation from 2001 to 2010. (The industry SBP is 0.15). The highest SBP of the Nigam is 0.36 whereas the lowest SBP of the power corporation is 0.01 . The $t$ value is 0 at $\mathrm{df}=9$ for two-tailed test. Thus, there is no significant change registered in secured borrowing performance of the corporation.

Table : 3 Secured Borrowing Performance (SBP) of Haryana Power Generation Corporation Limited (HPGCL) from 2001 to 2010

\begin{tabular}{|l|l|l|l|}
\hline Year & Secured Loan & Total Assets & SBP \\
\hline 2001 & 361.30 & 2082.00 & 0.17 \\
\hline 2002 & 379.72 & 2076.22 & 0.18 \\
\hline 2003 & 114.67 & 2533.10 & 0.05 \\
\hline 2004 & 208.58 & 3489.64 & 0.06 \\
\hline 2005 & 664.92 & 4408.14 & 0.15 \\
\hline
\end{tabular}


An analysis of secured and unsecured borrowing performance of the power corporations...

\begin{tabular}{|l|l|l|l|}
\hline 2006 & 2872.42 & 5731.28 & 0.50 \\
\hline 2007 & 3936.60 & 8398.97 & 0.47 \\
\hline 2008 & 5221.66 & 9524.36 & 0.55 \\
\hline 2009 & 4465.44 & 9337.86 & 0.48 \\
\hline 2010 & 5593.72 & 10061.74 & 0.56 \\
\hline Average & $\mathbf{2 3 8 1 . 9 0}$ & $\mathbf{5 7 6 4 . 3 3}$ & $\mathbf{0 . 3 2}$ \\
\hline
\end{tabular}

\section{One-Sample Test}

\begin{tabular}{|c|c|c|c|c|c|c|}
\hline & \multicolumn{6}{|c|}{ Test Value $=0.15$} \\
\hline & \multirow{2}{*}{$\mathbf{t}$} & \multirow{2}{*}{ df } & \multirow{2}{*}{$\begin{array}{l}\text { Sig. } \\
\text { tailed })\end{array}$} & \multirow{2}{*}{$\begin{array}{l}\text { Mean } \\
\text { Difference }\end{array}$} & \multicolumn{2}{|c|}{$\begin{array}{l}\text { 95\% Confidence Interval of } \\
\text { the Difference }\end{array}$} \\
\hline & & & & & Lower & Upper \\
\hline SBP & 2.497 & 9 & .034 & .16700 & .0157 & .3183 \\
\hline
\end{tabular}

Graph : 3

\section{Secured Borrowing Peformance}

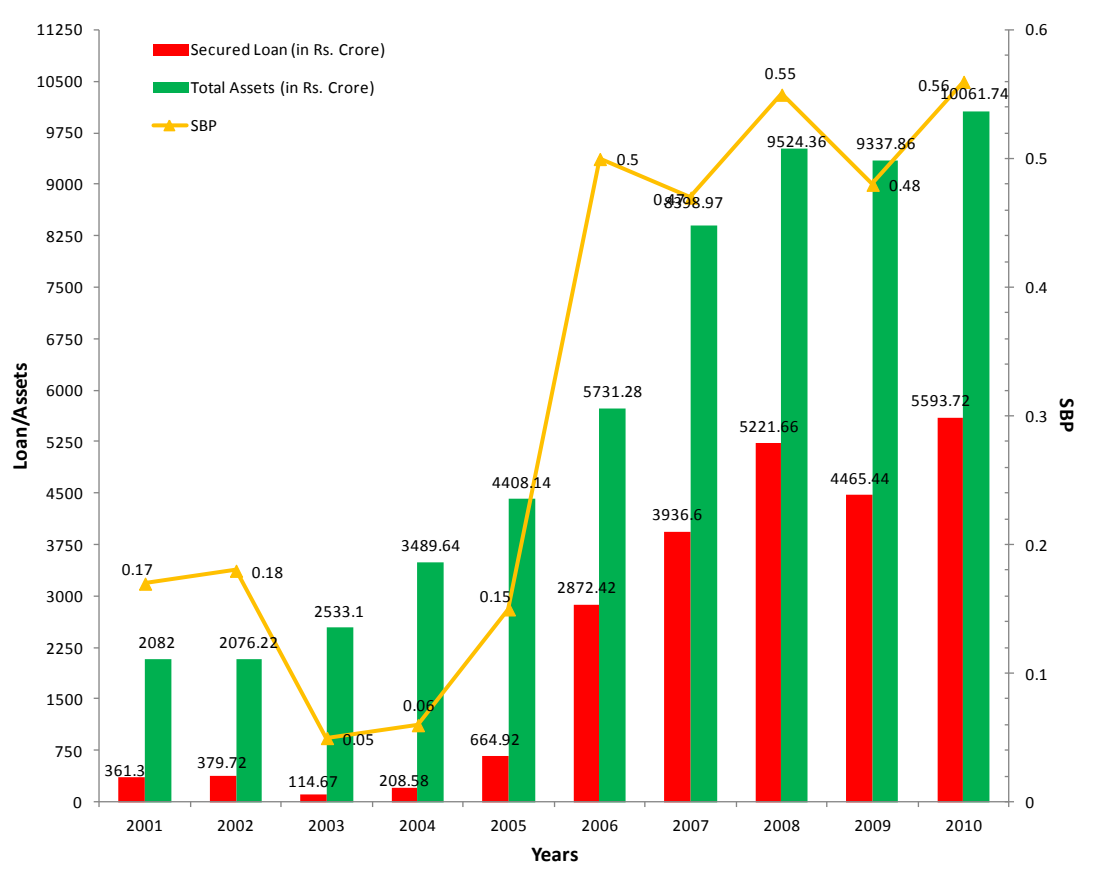

The secured borrowing performance (SBP) of the Haryana Power Generation Corporation Limited (HPGCL) is shown by table and graph :3 from 2001 to 2010. The secured loan for 2001 is ` 361.30 crore whereas 379.72 crore in 2002. The fluctuating trend is observed in secured loan from 2001 to 2010. The highest amount of loan is ` 5593.72 crore for 2010 whereas the lowest amount of secured loan is ` 114.67 crore for 2003. The average amount of loan is `2381.90 crore to the period under consideration for the study. The fluctuating trend is observed in total assets of the Corporation from 2001 to 2010. The highest amount of total assets of the corporation is ` 10061.74 crore whereas the lowest amount of total assets of the firm is `2076.22 crore for 2002. The average amount of total assets of the Nigam is` 5764.33 crore from 2001 to 2010. The average secured borrowing performance of the Vidut Nigam Ltd. is 0.32 that means, the $32 \%$ of the assets are secured against loan took by the corporation from 2001 to 2010. The highest SBP of the Nigam is 0.56 whereas 
An analysis of secured and unsecured borrowing performance of the power corporations... the lowest SBP of the power corporation is 0.05 . The $\mathrm{t}$ value is $\mathrm{t}=2.497$ at $\mathrm{df}=9$ for two-tailed test and significant at $5 \%$ level of risk. Thus, there is significant change registered in secured borrowing performance of the corporation from 2001 to 2010 .

Table : 4 Secured Borrowing Performance (SBP) of Haryana Vidut Prasaran Nigam Limited (HVPNL) from 2001 to 2010

(In`crore)

\begin{tabular}{|l|l|l|l|}
\hline Year & Secured Loan & Total Assets & SBP \\
\hline 2001 & 16.20 & 1897.52 & 0.01 \\
\hline 2002 & 15.90 & 2050.31 & 0.01 \\
\hline 2003 & 106.59 & 2131.63 & 0.05 \\
\hline 2004 & 54.56 & 2260.49 & 0.02 \\
\hline 2005 & 92.16 & 2563.42 & 0.04 \\
\hline 2006 & 100.67 & 3675.12 & 0.03 \\
\hline 2007 & 200.56 & 4028.06 & 0.05 \\
\hline 2008 & 397.67 & 4232.44 & 0.09 \\
\hline 2009 & 491.12 & 4911.21 & 0.10 \\
\hline 2010 & 571.67 & 6031.4 & 0.09 \\
\hline Average & $\mathbf{2 0 4 . 7 0}$ & $\mathbf{3 3 7 8 . 2}$ & $\mathbf{0 . 0 5}$ \\
\hline
\end{tabular}

One-Sample Test

\begin{tabular}{|l|l|l|l|l|l|l|}
\hline \multicolumn{3}{|l|}{ Test Value $=\mathbf{0 . 1 5}$} & & \multicolumn{2}{l|}{$\begin{array}{l}\text { 95\% Confidence Interval of the } \\
\text { Difference }\end{array}$} \\
\hline & & & & Sig. \\
& $\mathbf{t}$ & tailed $)$ & (2- & $\begin{array}{l}\text { Mean } \\
\text { Difference }\end{array}$ & Lower & Upper \\
\hline SBP & -9.446 & 9 & .000 & -.10100 & -.1252 & -.0768 \\
\hline
\end{tabular}


Graph : 4

\section{Secured Borrowing Peformance}

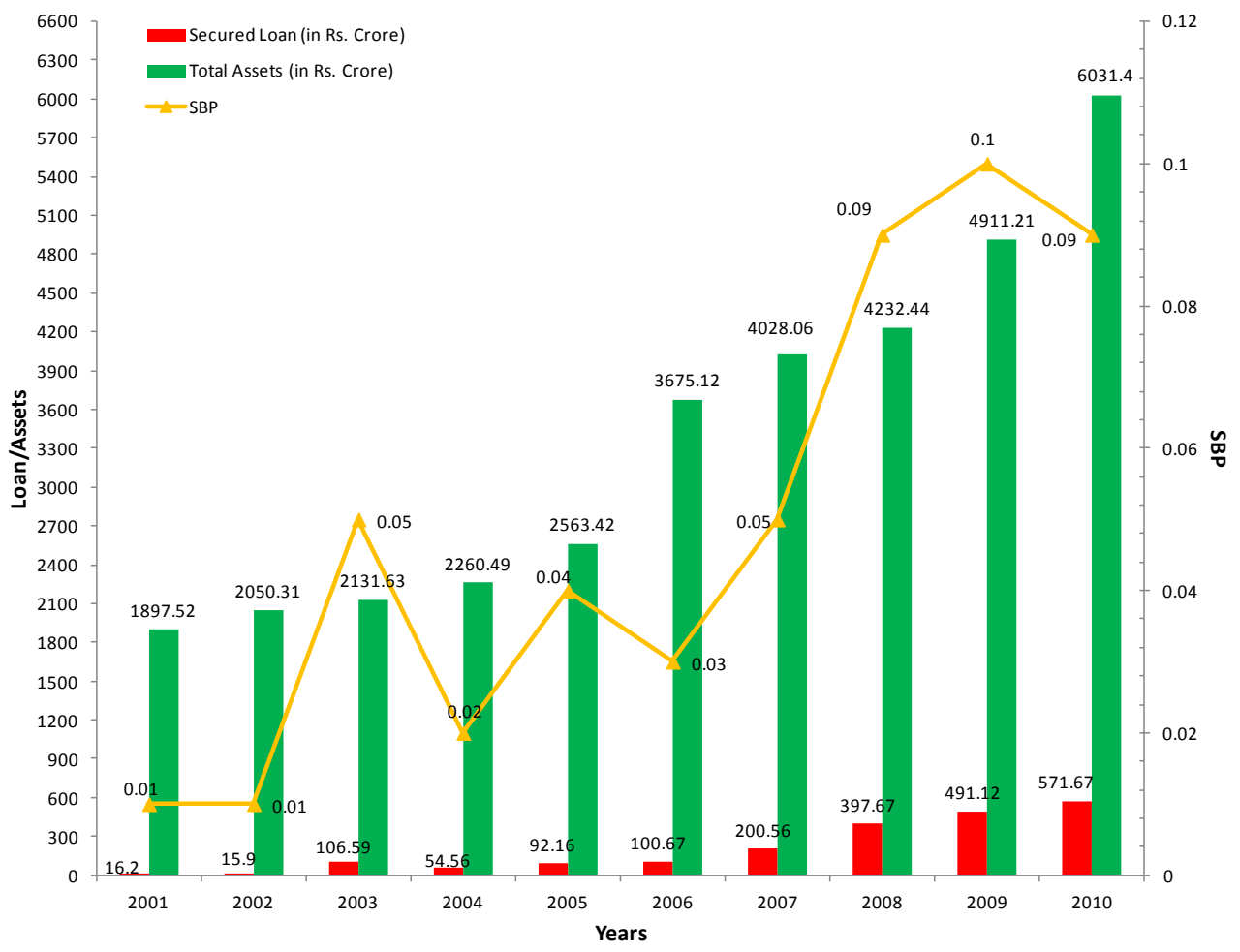

The secured borrowing performance (SBP) of the Haryana Vidyut Prasaran Nigam Limited (HVPNL) is shown by table and graph 4 from 2001 to 2010 . The secured loan for 2001 is ` 19.20 crore whereas - 571.67 crore in 2010. The fluctuating trend is observed in secured loan from 2001 to 2010. The highest amount of loan is ` 571.67 crore for 2010 whereas the lowest amount of secured loan is 15.90 crore for 2002 . The average amount of loan is ` 204.70 crore to the period under consideration for the study. The increasing trend is observed in total assets of the power corporation from 2001 to 2010 . The highest amount of total assets is ' 6031.40 crore whereas the lowest amount of total assets is ` 1897.52 crore for 2001 . The average amount of total assets is ` 3378.16 crore which is less as compared to the amount of net income of 2010 ( 6031.40 crore). The average secured borrowing performance of the Vidut Nigam ltd. is 0.05 that means, the $5 \%$ of the assets are secured against loan took by the corporation from 2001 to 2010. The highest SBP of the Nigam is 0.10 whereas the lowest SBP of the power corporation is 0.01 . The $\mathrm{t}$ value is $\mathrm{t}=-9.446$ at $\mathrm{df}=9$ for two-tailed test and significant at $1 \%$ level of risk. Thus, there is highly significant change registered in secured borrowing performance of the corporation from 2001 to 2010.

\section{Secured Borrowing Performance of Haryana Power Corporations}

Table\&Graph : 5 Secured Borrowing Performance of Haryana Power Corporations

\begin{tabular}{|l|l|l|l|l|}
\hline & $\begin{array}{l}\text { Dakshin } \\
\text { Yaryana Bijli } \\
\text { Vitran Nigam } \\
\text { Limited } \\
\text { (DHBVNL) }\end{array}$ & $\begin{array}{l}\text { Uttar Haryana } \\
\text { Bijli Vitran } \\
\text { Nigam Limited } \\
\text { (UHBVNL) }\end{array}$ & $\begin{array}{l}\text { Haryana } \\
\text { Power } \\
\text { Generation } \\
\text { Corporation } \\
\text { Limited } \\
\text { (HPGCL) }\end{array}$ & $\begin{array}{l}\text { Haryana Vidut } \\
\text { Prasaran } \\
\text { Nigam Limited } \\
\text { (HVPNL) }\end{array}$ \\
\hline $\mathbf{2 0 0 1}$ & 0.01 & 0.01 & 0.17 & 0.01 \\
\hline $\mathbf{2 0 0 2}$ & 0.03 & 0.06 & 0.18 & 0.01 \\
\hline $\mathbf{2 0 0 3}$ & 0.05 & 0.11 & 0.05 & 0.05 \\
\hline $\mathbf{2 0 0 4}$ & 0.02 & 0.13 & 0.06 & 0.02 \\
\hline
\end{tabular}


An analysis of secured and unsecured borrowing performance of the power corporations...

\begin{tabular}{|c|c|c|c|c|}
\hline 2005 & 0.04 & 0.11 & 0.15 & 0.04 \\
\hline 2006 & 0.05 & 0.09 & 0.50 & 0.03 \\
\hline 2007 & 0.10 & 0.13 & 0.47 & 0.05 \\
\hline 2008 & 0.18 & 0.15 & 0.55 & 0.09 \\
\hline 2009 & 0.16 & 0.36 & 0.48 & 0.10 \\
\hline 2010 & 0.32 & 0.35 & 0.56 & 0.09 \\
\hline Average & 0.10 & 0.15 & 0.32 & 0.05 \\
\hline $\mathbf{T}-$ Test & $\begin{array}{l}\text { T-value }=-1.74 \\
\text { Sig. at }=.11\end{array}$ & $\begin{array}{l}T-\text { value }=0 \\
\text { Sig. at }=1\end{array}$ & $\begin{array}{l}\text { T-value }=2.49 \\
\text { Sig. at }=.03\end{array}$ & $\begin{array}{l}\text { T-value }=-9.44 \\
\text { Sig. at }=0\end{array}$ \\
\hline
\end{tabular}


Comparative Appraisal of Secured Borrowing Performance of Haryana Power Corporations

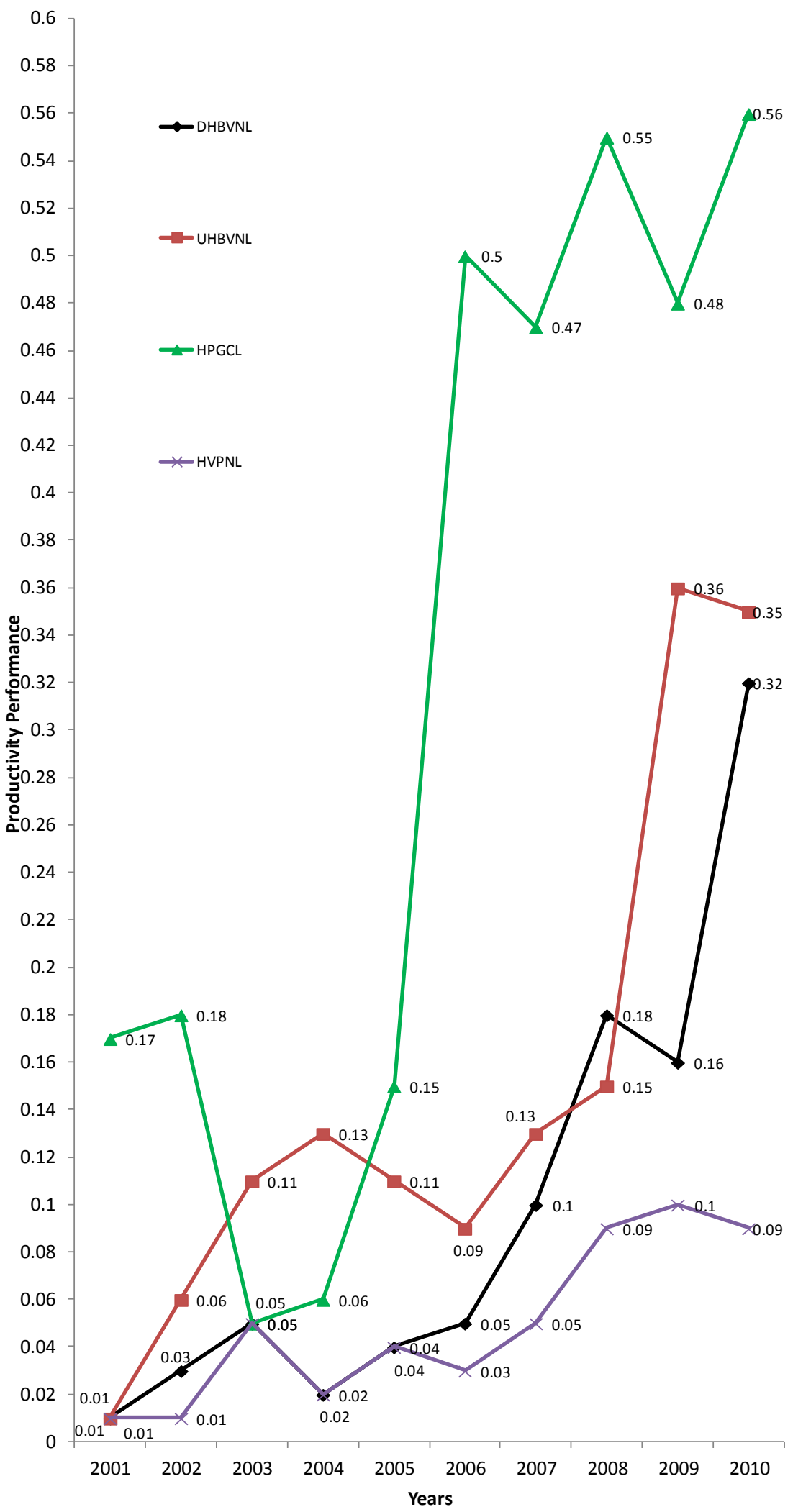

Table and Graph :5 shows the average secured borrowing performance (SBP) of Haryana Power Generation Corporation Limited (HPGCL) and Haryana Vidut Prasaran Nigam Limited (HVPNL) is 0.32 and 0.05 respectively. The SBP of Haryana Power Generation Corporation Ltd. is significant at $\boldsymbol{\alpha}=.05$ which 
An analysis of secured and unsecured borrowing performance of the power corporations... means that the corporation took more secured loan during 2001 to 2010. The secured borrowing performance of Haryana Vidut Prasaran Nigam Limited (HVPNL) is also significant at $\boldsymbol{\alpha}=.01$ which means that the corporation took more loan during 10 years. Thus, null hypothesis $\left(\mathrm{H}_{0}\right)$ is rejected for SBP of Haryana Power Generation Corporation Limited (HPGCL) and Haryana Vidut Prasaran Nigam Limited (HVPNL).

Unsecured Borrowing Performance (USBP)

Table : 6 Unsecured Borrowing Performance (USBP) of Dakshin Haryana Bijli Vitran Nigam Limited (DHBVNL) from 2001 to 2010

\begin{tabular}{|c|c|c|c|}
\hline \multicolumn{4}{|c|}{ (In`crore) } \\
\hline Year & U. Secured Loan & Total Assets & USBP \\
\hline 2001 & 210.21 & 1910.10 & 0.11 \\
\hline 2002 & 373.26 & 2032.17 & 0.18 \\
\hline 2003 & 396.83 & 2040.43 & 0.19 \\
\hline 2004 & 453.04 & 2553.42 & 0.18 \\
\hline 2005 & 367.56 & 2257.42 & 0.16 \\
\hline 2006 & 375.00 & 3116.15 & 0.12 \\
\hline 2007 & 631.30 & 2613.47 & 0.24 \\
\hline 2008 & 806.47 & 2879.46 & 0.28 \\
\hline 2009 & 1451.84 & 5999.02 & 0.24 \\
\hline 2010 & 1226.09 & 8314.68 & 0.15 \\
\hline Average & 629.16 & 3371.63 & 0.19 \\
\hline
\end{tabular}

One-Sample Test

\begin{tabular}{|c|c|c|c|c|c|c|}
\hline & \multicolumn{6}{|c|}{ Test Value $=.26$} \\
\hline & \multirow{2}{*}{$\mathbf{t}$} & \multirow{2}{*}{ df } & \multirow{2}{*}{$\begin{array}{l}\text { Sig. } \\
\text { tailed })\end{array}$} & \multirow{2}{*}{$\begin{array}{l}\text { Mean } \\
\text { Difference }\end{array}$} & \multicolumn{2}{|c|}{$\begin{array}{l}\text { 95\% Confidence Interval of } \\
\text { the Difference }\end{array}$} \\
\hline & & & & & Lower & Upper \\
\hline USBP & -4.342 & 9 & .002 & -.07500 & -.1141 & -.0359 \\
\hline
\end{tabular}

Graph: 6 


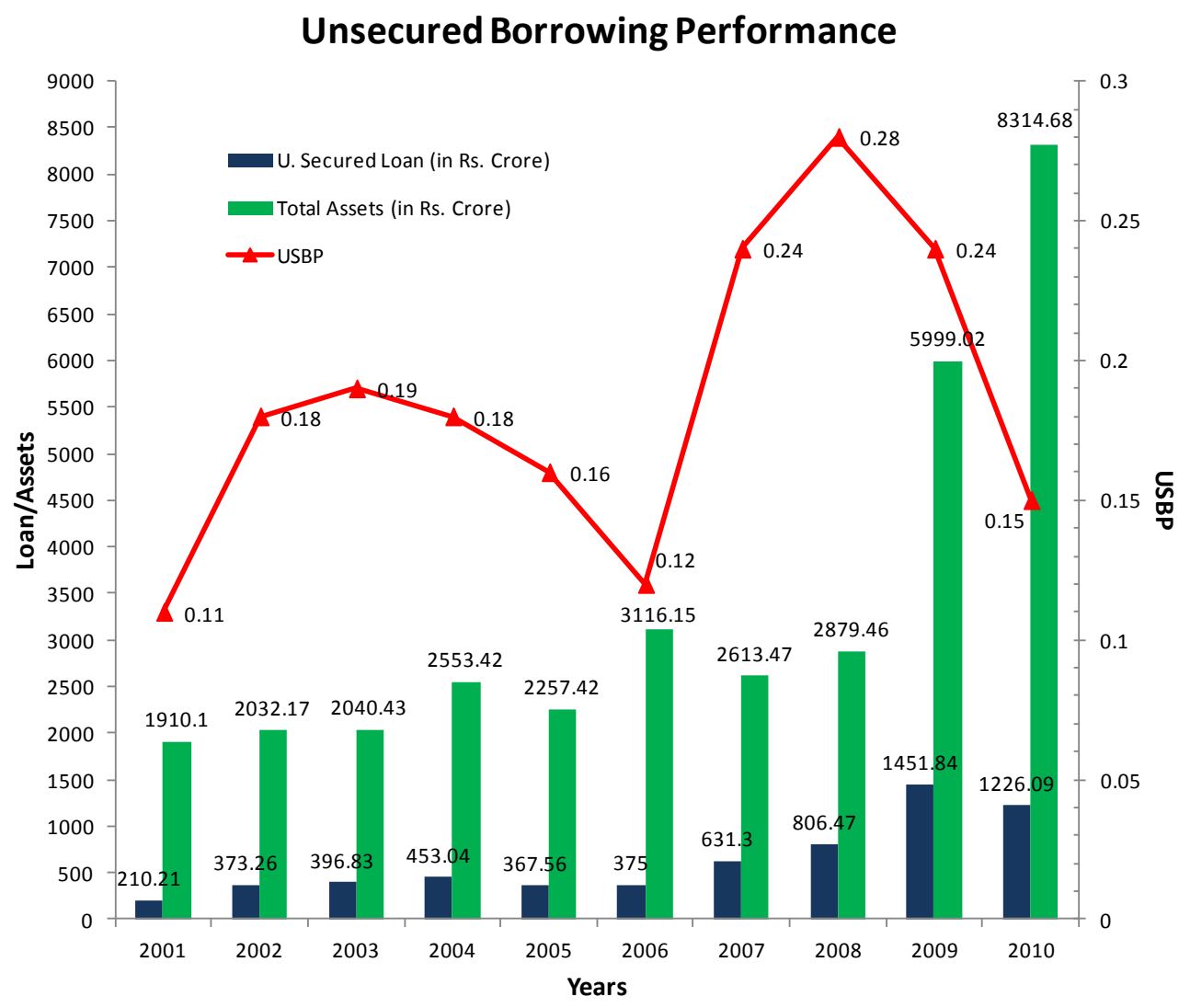

The unsecured borrowing performance of the corporation has been shown by table: and graph :6 for the period i.e. 2001 to 2010. The fluctuating trend has been observed in unsecured loan of the corporation from 2001 to 2010. The highest amount of unsecured loan is ` 1451.84 crore in 2009 whereas the lowest amount of unsecured loan is `210.21 crore for 2001. The average amount of unsecured loan is` 629.16 crore which is less as compared to the amount of 2007 ( 631.30 crore), 2008 (` 806.47 crore), 2009 (` 1451.84 crore) and 2010 ( 1226.09 crore). The fluctuating trend is observed in total assets of the Nigam from 2001 to 2010. The highest amount of total assets is ` 8314.68 crore in 2010 whereas the lowest amount of total assets is ` 1910.10 crore for 2001. The average amount of total assets is` 3371.63 crore which is five times more as compared to the unsecured loan of the corporation. The highest USBP of the corporation is 0.28 for 2008 and the lowest USBP is 0.11 for 2001. (Industry USBP is 0.26) The average USBP of the Dakshin Haryana Bijli Vitran Nigam Limited (DHBVNL) is 0.19 which is more as compared to the value of 2001 (0.11), $2002(0.18), 2004(0.18), 2005$ (0.16), $2006(0.12)$ and $2010(0.15)$. The USBP ratio is also tested through t-test (two-tailed) at $5 \%$ level of risk The $t$ value of the USBP $t=-4.342$ at $\mathrm{df}=9$ and significant at 5 percent and even at 1 percent level of risk. Thus, the unsecured borrowing performance of the corporation is highly significantly changed from 2001 to 2010.

Table : 7 Unsecured Borrowing Performance (USBP) of Uttar Haryana Bijli Vitran Nigam Limited (UHBVNL) from 2001 to 2010

\begin{tabular}{|l|l|l|l|}
\hline Year & U. Secured Loan & Total Assets & USBP \\
\hline 2001 & 328.92 & 2196.26 & 0.15 \\
\hline 2002 & 579.03 & 2092.82 & 0.28 \\
\hline 2003 & 712.94 & 2224.04 & 0.32 \\
\hline 2004 & 637.03 & 2436.32 & 0.26 \\
\hline 2005 & 588.96 & 2916.55 & 0.20 \\
\hline
\end{tabular}


An analysis of secured and unsecured borrowing performance of the power corporations...

\begin{tabular}{|l|l|l|l|}
\hline 2006 & 756.43 & 3096.49 & 0.24 \\
\hline 2007 & 1259.99 & 4082.11 & 0.31 \\
\hline 2008 & 2079.47 & 5344.09 & 0.39 \\
\hline 2009 & 1990.38 & 7871.73 & 0.25 \\
\hline 2010 & 3639.42 & 12370.4 & 0.29 \\
\hline Average & $\mathbf{1 2 5 7 . 2 6}$ & $\mathbf{4 4 6 3 . 0 8}$ & $\mathbf{0 . 2 7}$ \\
\hline
\end{tabular}

One-Sample Test

\begin{tabular}{|c|c|c|c|c|c|c|}
\hline & \multicolumn{6}{|c|}{ Test Value $=0.26$} \\
\hline & \multirow{2}{*}{ t } & \multirow{2}{*}{ df } & \multirow{2}{*}{$\begin{array}{l}\text { Sig. } \\
\text { tailed })\end{array}$} & \multirow{2}{*}{$\begin{array}{l}\text { Mean } \\
\text { Difference }\end{array}$} & \multicolumn{2}{|c|}{$\begin{array}{l}95 \% \text { Confidence Interval of the } \\
\text { Difference }\end{array}$} \\
\hline & & & & & Lower & Upper \\
\hline USBP & .429 & 9 & .678 & .00900 & -.0385 & .0565 \\
\hline
\end{tabular}


Graph : 7

\section{Unsecured Borrowing Performance}

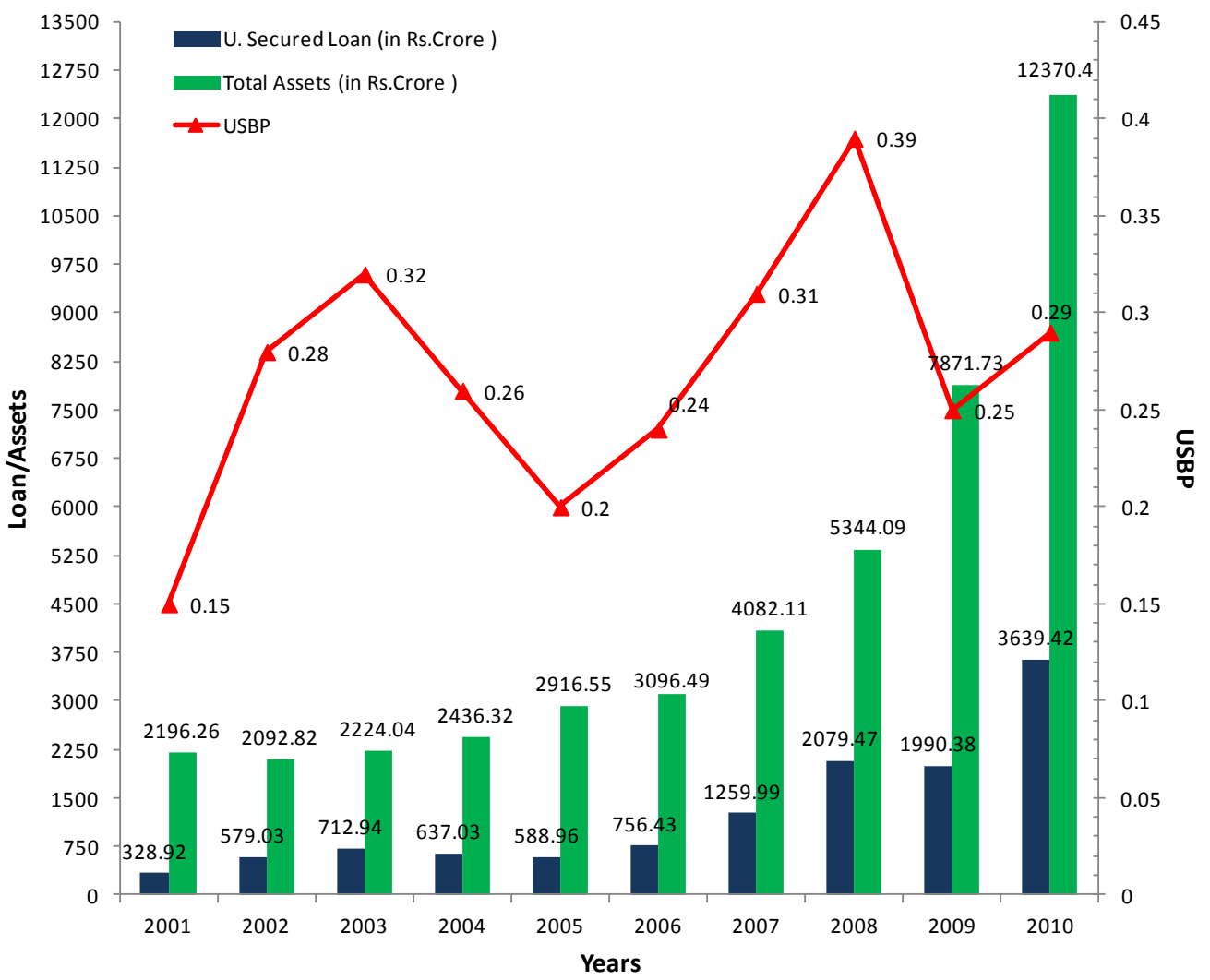

The unsecured borrowing performance of the corporation is shown by table and graph:7 from 2001 to 2010. The unpredictable trend is observed in unsecured loan of the Corporation from 2001 to 2010. The highest amount of unsecured loan is ` 3639.42 crore whereas the lowest amount of unsecured loan is ` 328.92 crore for 2001. The average amount of unsecured loan is ` 1257.26 crore which is less as compared to the amount of 2007 (' 1259.99 crore), 2008 ( 2079.47 crore), 2009 ( 1990.38 crore) and 2010 ( 3639.42 crore). The fluctuating trend is observed in total assets of the Corporation from 2001 to 2010. The highest amount of total assets of the corporation is ` 12370.40 crore whereas the lowest amount of total assets of the firm is `2092.82 crore for 2002. The average amount of total assets of the Nigam is ` 4463.08 crore from 2001 to 2010 . The highest USBP of the corporation is 0.39 for 2008 and the lowest USBP is 0.15 for 2001. The average USBP of the Uttar Haryana Bijli Vitran Nigam Limited (UHBVNL) is 0.27 which is more as compared to the value of 2001 (0.15), 2004 (0.26), $2005(0.20), 2006(0.24)$ and $2009(0.25)$. The $t$ value of the USBP $t=-0.429$ at $\mathrm{df}=9$ and not significant at any level of risk. Thus, the unsecured borrowing performance of the corporation is not significantly changed from 2001 to 2010.

Table : 8 Unsecured Borrowing Performance (USBP) of Haryana Power Generation Corporation Limited (HPGCL) from 2001 to 2010

\begin{tabular}{|l|l|l|l|}
\hline Year & U. Secured Loan & Total Assets & USBP \\
\hline 2001 & 1120.71 & 2082.00 & 0.54 \\
\hline 2002 & 1108.42 & 2076.22 & 0.53 \\
\hline 2003 & 1665.76 & 2533.10 & 0.66 \\
\hline 2004 & 2258.77 & 3489.64 & 0.65 \\
\hline 2005 & 2570.63 & 4408.14 & 0.58 \\
\hline
\end{tabular}


An analysis of secured and unsecured borrowing performance of the power corporations...

\begin{tabular}{|l|l|l|l|}
\hline 2006 & 1045.06 & 5731.28 & 0.18 \\
\hline 2007 & 1173.07 & 8398.97 & 0.14 \\
\hline 2008 & 470.18 & 9524.36 & 0.05 \\
\hline 2009 & 436.66 & 9337.86 & 0.05 \\
\hline 2010 & 392.66 & 10061.74 & 0.04 \\
\hline Average & $\mathbf{1 2 2 4 . 1 9}$ & $\mathbf{5 7 6 4 . 3 3}$ & $\mathbf{0 . 3 4}$ \\
\hline
\end{tabular}

\section{One-Sample Test}

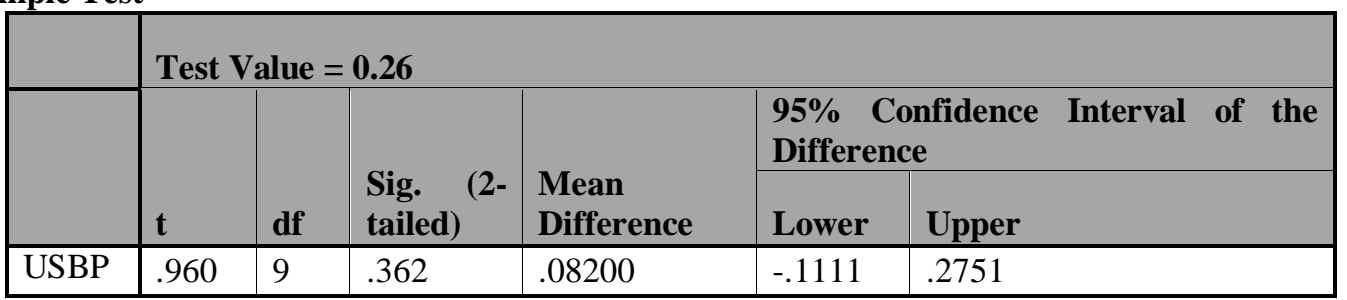

\section{Graph : 8}

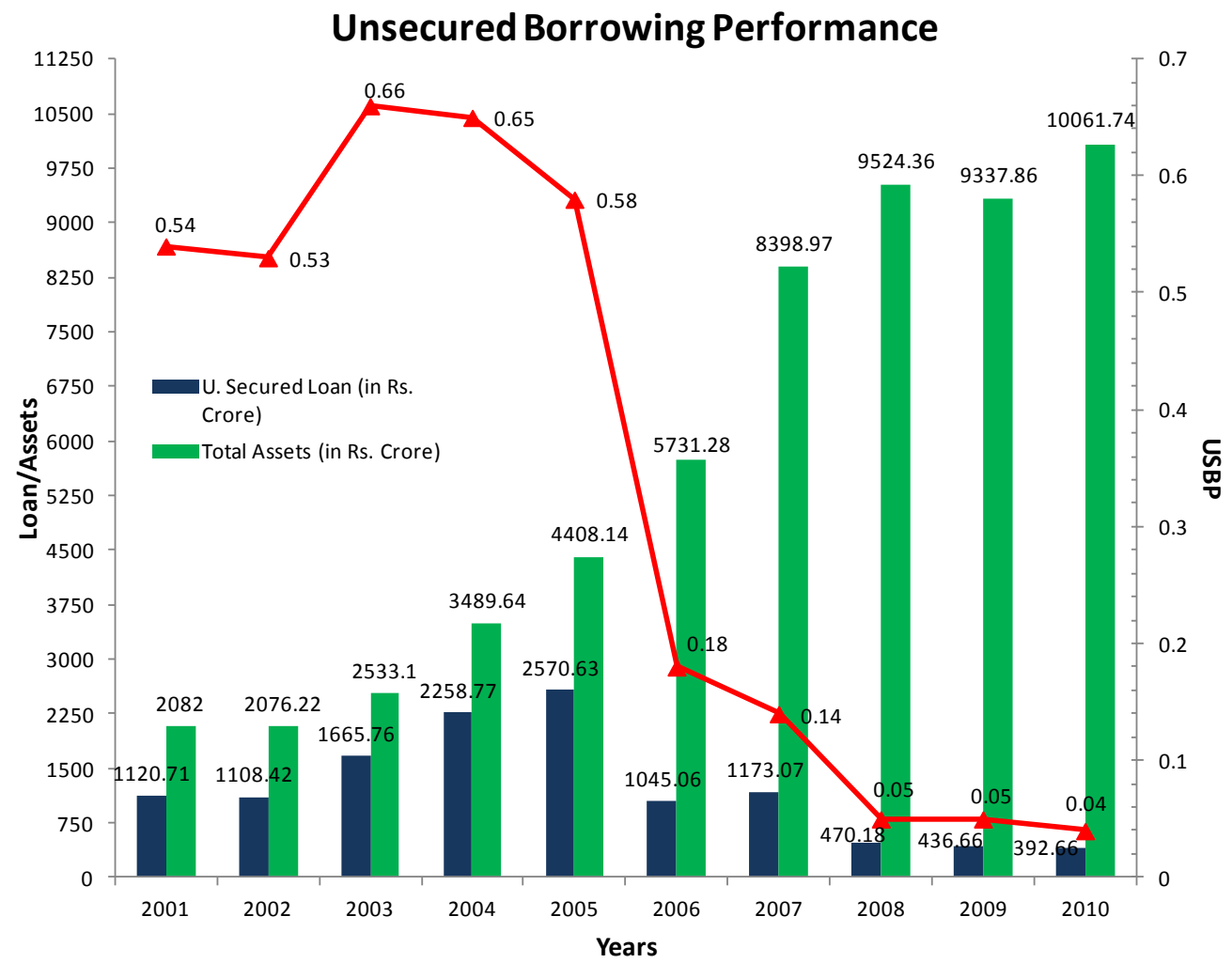

The unsecured borrowing performance of the corporation is shown by table : 20 from 2001 to 2010 . The fluctuating trend is observed in unsecured loan of the Corporation from 2001 to 2010. The highest amount of unsecured loan is` 2570.63 crore whereas the lowest amount of unsecured loan is`392.66 crore for 2001. The average amount of unsecured loan is ` 1224.19 crore which is more as compared to the amount of 2010 (C 392.66 crore), 2009 ( 436.66 crore) and 2008 ( 470.18 crore).The fluctuating trend is observed in total assets of the power corporation from 2001 to 2010 . The highest amount of total assets is ` 10061.74 crore whereas the lowest amount of total assets is ` 2076.22 crore for 2002 . The average amount of total assets is ` 5764.33 crore which is more as compared to the average amount of unsecured loan ( 1224.19 crore). The highest USBP of the corporation is 0.66 for 2003 and the lowest USBP is 0.04 for 2010. The average USBP of the Haryana 
An analysis of secured and unsecured borrowing performance of the power corporations... Power Generation Corporation Limited (HPGCL) is 0.34 which is more as compared to the value of 2006 to 2010. The $t$ value of the USBP $t=0.960$ at $d f=9$ and not significant at any level of risk. Thus the unsecured borrowing performance of the corporation has not significantly changed from 2001 to 2010.

Table :9 Unsecured Borrowing Performance (USBP) of Haryana Vidut Prasaran Nigam Limited (HVPNL) from 2001 to 2010

(In`crore)

\begin{tabular}{|l|l|l|l|}
\hline Year & U. Secured Loan & Total Assets & USBP \\
\hline 2001 & 210.21 & 1897.52 & 0.11 \\
\hline 2002 & 423.26 & 2050.31 & 0.21 \\
\hline 2003 & 396.83 & 2131.63 & 0.19 \\
\hline 2004 & 453.04 & 2260.49 & 0.20 \\
\hline 2005 & 367.56 & 2563.42 & 0.14 \\
\hline 2006 & 967.56 & 3675.12 & 0.26 \\
\hline 2007 & 1072.13 & 4028.06 & 0.27 \\
\hline 2008 & 1275.67 & 4232.44 & 0.30 \\
\hline 2009 & 1651.16 & 4911.21 & 0.34 \\
\hline 2010 & 2056.27 & 6031.40 & 0.34 \\
\hline Average & $\mathbf{8 8 7 . 3 7}$ & $\mathbf{3 3 7 8 . 1 6}$ & $\mathbf{0 . 2 4}$ \\
\hline
\end{tabular}

One-Sample Test

\begin{tabular}{|c|c|c|c|c|c|c|}
\hline & \multicolumn{6}{|c|}{ Test Value $=0.26$} \\
\hline & \multirow[b]{2}{*}{$\mathbf{t}$} & \multirow[b]{2}{*}{ df } & \multirow{2}{*}{$\begin{array}{l}\text { Sig. } \\
\text { tailed) }\end{array}$} & \multirow{2}{*}{$\begin{array}{l}\text { Mean } \\
\text { Difference }\end{array}$} & \multicolumn{2}{|c|}{$\begin{array}{l}\text { 95\% Confidence Interval of the } \\
\text { Difference }\end{array}$} \\
\hline & & & & & Lower & Upper \\
\hline USBP & -.957 & 9 & .364 & -.02400 & -.0807 & .0327 \\
\hline
\end{tabular}


Graph : 9

Unsecured Borrowing Performance

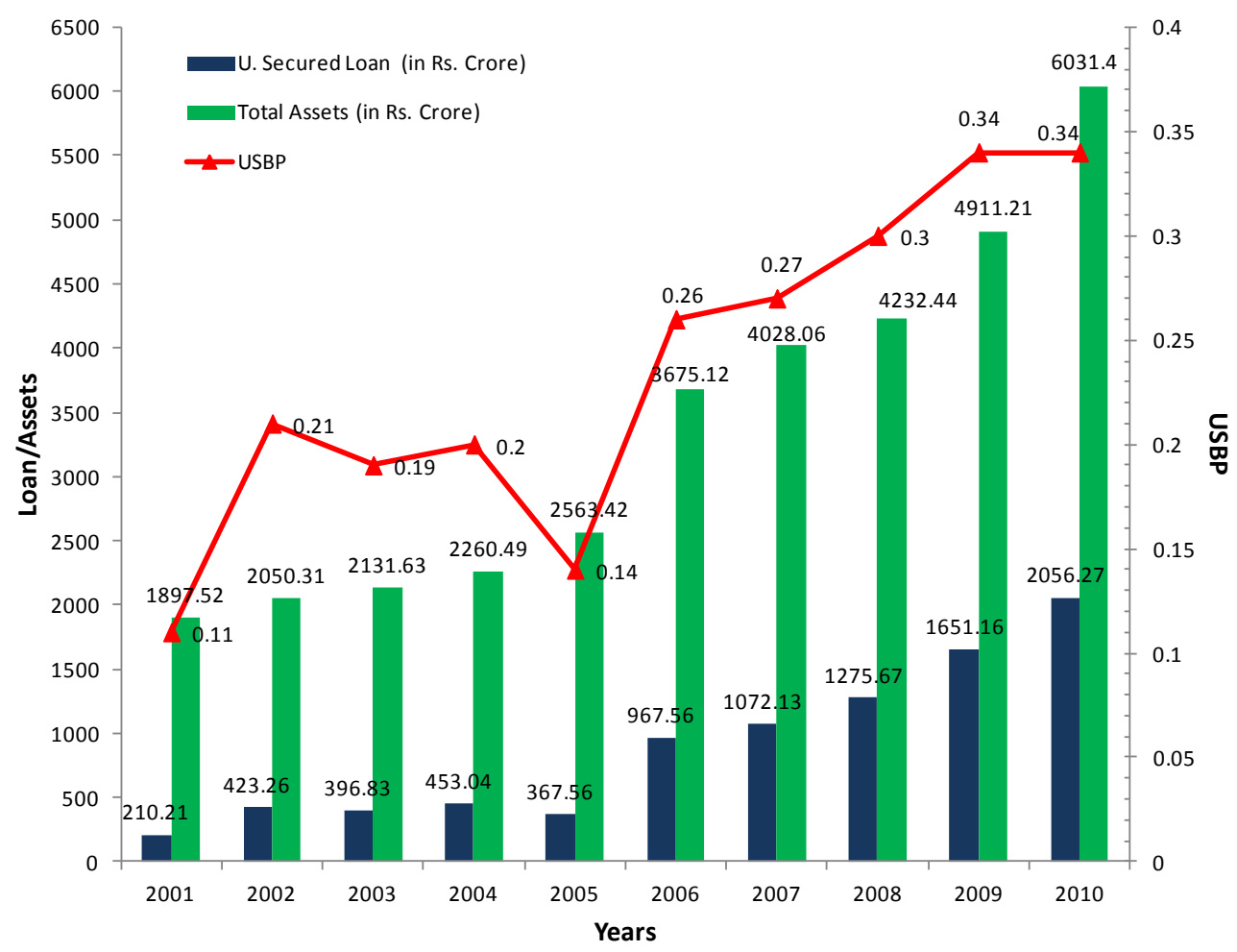

The unsecured borrowing performance (USBP) of Haryana Vidut Prasaran Nigam Limited (HVPNL) is shown by table and graph:9 from 2001 to 2010. The fluctuating trend is observed in unsecured loan from 2001 to 2010 . The amount of loan for 2001 is `210.21 crore whereas ` 423.26 crore for 2002 . The highest amount of unsecured loan is `2056.27 crore whereas the lowest amount of unsecured loan is `210.21 crore for 2001 . The average amount of unsecured loan is ` 887.37 crore which is less as compared to the amount of 2010 ( 2056.27 crore). The highest amount of total assets is ` 6031.40 crore whereas the lowest amount of total assets is 1897.52 crore for 2001 . The average amount of total assets is ` 3378.16 crore which is less as compared to the amount of net income of 2010 ( 6031.40 crore). The increasing trend is observed in total assets of the HPVNL from 2001 to 2010. The highest unsecured borrowing performance (USBP) is 0.34 whereas the lowest ratio is 0.11 for 2001 . The average ratio is 0.24 which is less as compared to performance ratio of 2010 . The unsecured borrowing performance is also tested through $\mathrm{t}$ test where $\mathrm{t}$ value is $(\mathrm{t}=-0.957)$ with $\mathrm{df}=9$ and not significant at any level of risk. Thus, there is no significant change recorded in unsecured borrowing performance from 2001 to 2010 .

\section{Unsecured Borrowing Performance of Haryana Power Corporations}

Table \& Graph : 10 Unsecured Borrowing Performance of Haryana Power Corporations

\begin{tabular}{|l|l|l|l|l|}
\hline & $\begin{array}{l}\text { Dakshin } \\
\text { Haryana Bijli } \\
\text { Vitran Nigam } \\
\text { Limited } \\
\text { (DHBVN) }\end{array}$ & $\begin{array}{l}\text { Uttar Haryana } \\
\text { Bijli Vitran } \\
\text { Nigam Limited } \\
\text { (UHBVN) }\end{array}$ & $\begin{array}{l}\text { Haryana } \\
\text { Power } \\
\text { Generation } \\
\text { Corporation } \\
\text { Limited } \\
\text { (HPGCL) }\end{array}$ & $\begin{array}{l}\text { Haryana Vidut } \\
\text { Prasaran } \\
\text { Nigam Limited } \\
\text { (HVPNL) }\end{array}$ \\
\hline 2001 & 0.11 & 0.15 & 0.54 & 0.11 \\
\hline 2002 & 0.18 & 0.28 & 0.53 & 0.21 \\
\hline 2003 & 0.19 & 0.32 & 0.66 & 0.19 \\
\hline 2004 & 0.18 & 0.26 & 0.65 & 0.20 \\
\hline 2005 & 0.16 & 0.20 & 0.58 & 0.14 \\
\hline
\end{tabular}


An analysis of secured and unsecured borrowing performance of the power corporations...

\begin{tabular}{|l|l|l|l|l|}
\hline 2006 & 0.12 & 0.24 & 0.18 & 0.26 \\
\hline 2007 & 0.24 & 0.31 & 0.14 & 0.27 \\
\hline 2008 & 0.28 & 0.39 & 0.05 & 0.30 \\
\hline 2009 & 0.24 & 0.25 & 0.05 & 0.34 \\
\hline 2010 & 0.15 & 0.29 & 0.04 & 0.34 \\
\hline Average & $\mathbf{0 . 1 9}$ & $\mathbf{0 . 2 7}$ & $\mathbf{0 . 3 4}$ & $\mathbf{0 . 2 4}$ \\
\hline T - Test & $\begin{array}{l}\text { T-value }=\mathbf{4 . 3 4} \\
\text { Sig. at }=\mathbf{. 0 0 2}\end{array}$ & $\begin{array}{l}\text { T-value }=\mathbf{. 4 2} \\
\text { Sig. } \mathbf{a t}=\mathbf{. 6 7}\end{array}$ & $\begin{array}{l}\text { T-value=-5.77 } \\
\text { Sig. at }=\mathbf{. 0 0}\end{array}$ & $\begin{array}{l}\text { T-value=2.21 } \\
\text { Sig. at }=\mathbf{. 0 5}\end{array}$ \\
\hline
\end{tabular}


Comparative Appraisal of Unsecured Borrowing Performance of Haryana Power Corporations

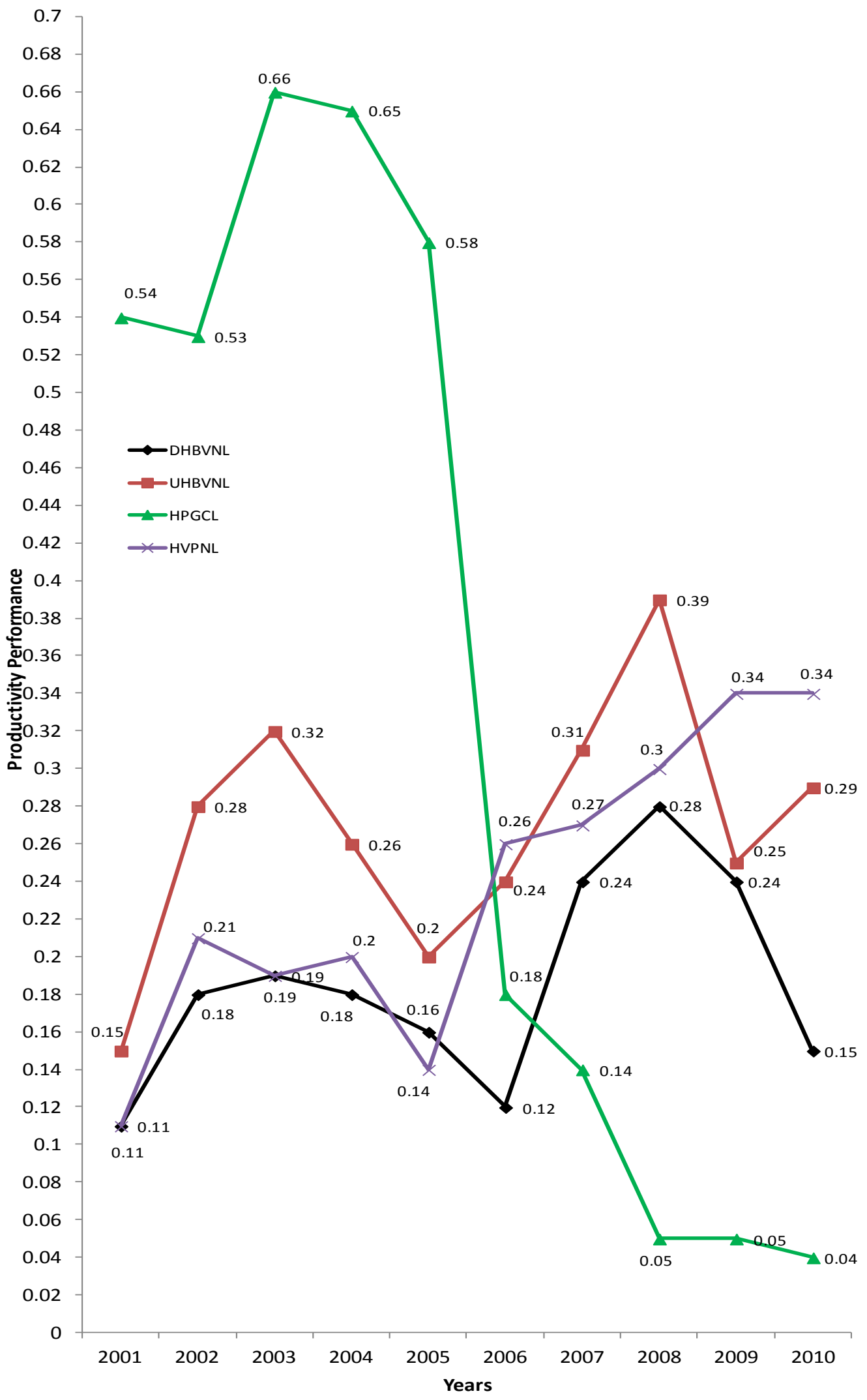

Table and graph 10 shows the average unsecured borrowing performance (USBP) of Dakshin Haryana Bijli Vitran Nigam Limited (DHBVNL) is $\mathbf{0 . 1 9}$ which is significant at $\boldsymbol{\alpha}=.01$. The average USBP of Haryana Power Generation Corporation Limited (HPGCL) and Haryana Vidut Prasaran Nigam Limited (HVPNL) is 
An analysis of secured and unsecured borrowing performance of the power corporations...

$\mathbf{0 . 3 4}$ and $\mathbf{0 . 2 4}$ which are significant at $1 \%$ and $5 \%$ level of risk. Haryana Power Generation Corporation Limited (HPGCL) and Haryana Vidut Prasaran Nigam Limited (HVPNL) tool more unsecured loan for their operations. Thus, null hypothesis $\left(\mathrm{H}_{0}\right)$ is rejected for USBP of Haryana Power Generation Corporation Limited (HPGCL) and Haryana Vidut Prasaran Nigam Limited (HVPNL). The average USBP for Uttar Haryana Bijli Vitran Nigam Limited (UHBVNL), Haryana Power Generation Corporation Limited (HPGCL) and Haryana Vidut Prasaran Nigam Limited (HVPNL) is $\mathbf{0 . 0 6}, \mathbf{0 . 0 6}$ and 0.05 respectively which are not significant at specified level of risk. The average depreciation performance of Dakshin Haryana Bijli Vitran Nigam Limited (DHBVNL) is $\mathbf{0 . 0 5}$ which is significant at $10 \%$ level of risk. Thus, null hypothesis $\left(\mathrm{H}_{0}\right)$ is rejected for USBP for Dakshin Haryana Bijli Vidut Nigam Ltd.

\section{Conclusion}

Secured borrowings shows for Haryana Power Generation Corporation Limited (HPGCL) and Haryana Vidut Prasaran Nigam Limited (HVPNL) Null hypothesis is rejected. It shows they took more secured loans and revenue generation is not so good .And unsecured borrowings shows for Dakshin Haryana Bijli Vitran Nigam Limited (DHBVNL) Null hypothesis is rejected. It shows situation of this nigam is worst because it took loans and even unsecured loans.

\section{Suggestions}

1. The secured borrowing performance of HVPNL is also significant at $\boldsymbol{\alpha}=.01$ which means that the corporation took more loan during 10 years. Thus, the power unit is directed by the study to manage the working capital for day to day operational activities.

2. Efforts are done for revenue generation so that nigams shouldnot be dependent on loan and process of development should run without any hurdle.

3. Work should be done with efficiency so that wastage of resources should be avoided and it will become helpful in generating resources and reducing loans.

\section{References}

[1]. Raghuram G., Jain Rekha, Morris Sebastian, Infrastructural Development and Financing - Project Report "The Haryana State Electricity Board Tariff Award - A Critical Review".

[2]. Mishra Sarbesh, Power Sector Reforms in India: A Critical Appraisal of Orissa's Reforms Indian Journal of Commerce, Vol 10, issue 5, pg 45-78.

[3]. Shukla P.R., Biswas Debashish, Victor David G, Impact of Power Sector Reforms on Technology, Efficiency and Emissions: Case Study of Andhra Pradesh, India Working Paper \#20, March 2004, Pg-1-19.

[4]. Singh Jitendra, Proceedings of ASCNT - 2005, CDAC, Noida, India, pp. 127 - 132.

[5]. Malhotra Paras \& Singh Negi Shivraj, "Power Sector Reforms in Delhi-An enquiry into outcome of reforms, claims of power sufficiency and the road ahead" Working Paper No 228 Summer Research Internship 2009 